\title{
Karakteristik Toksisitas Hidroksiapatit yang Disintesis dari Kalsit Terhadap Rattus norvegicus
}

\author{
Siti Sunarintyas \\ Minat Studi Rekayasa Biomedis, Prodi Bioteknologi \\ Sekolah Pascasarjana Universitas Gadjah Mada \\ Email: sunarintyassiti@yahoo.com \\ Isti Rahayu Suryani \\ Fakultas Kedokteran Gigi Universitas Gadjah Mada
}

\begin{abstract}
The use of synthetic hydroxyapatite (HA) in biomedical application is well warranted. It has shown to have an excellent biocompatibility in human tooth and bones. The present study was conducted to know the toxicity characteristics of hydroxyapatite synthesized from Mojokerto calcite in Rattus norvegicus. In this study 30 Rattus norvegicus were used as experimental animals. The animals were divided into 3 groups $(n=10)$ to be given HA-calcite, HA-200 (Waco, Japan), and aquadest (control) orally. The animals were observed 7 days and then were analyzed for: fatality rate and clinical behavior, hematology test, organ morphology, and histopathology appearance. The result showed that there was not any animal death during 7 days observation. None of the animal exhibited any noteworthy findings in clinical behavior, hematology test, organ morphology, and histopathology appearance. In conclusion, HA-calcite did not show any acute toxicity characteristic; therefore, it was potential to be used as an alternative material for bone substitution.
\end{abstract}

Keywords: hydroxyapatite, toxicity, Rattus norvegicus

\begin{abstract}
ABSTRAK
Pemakaian hidroksiapatit sintetik pada bidang biomedis baru menjadi tren saat ini. Hidroksiapatit sintetik diketahui mempunyai sifat biokompatibilitas yang baik pada tulang dan gigi. Penelitian ini bertujuan untuk mengetahui karakteristik toksisitas hidroksiapatit yang disintesis dari kalsit (Mojokerto) pada Rattus norvegicus sebagai hewan coba. Hewan coba dibagi dalam 3 (tiga) kelompok $(\mathrm{n}=10)$ untuk diberi paparan HA-kalsit (Mojokerto), HA-200 (Waco, Jepang), dan akuades (kontrol) peroral. Hewan coba di observasi selama 7 hari kemudian dianalisis untuk kematian, tingkah laku klinis, kompatibilitas darah, morfologi organ, dan gambaran histopatologis. Tidak satu pun hewan coba menunjukkan abnormalitas dalam tingkah laku klinis, tes hematologi, morfologi organ, dan gambaran histopatologi. HA-kalsit tidak menunjukkan karakteristik toksisitas akut sehingga berpotensi untuk digunakan sebagai alternatif material pengganti tulang.
\end{abstract}

Kata Kunci: hidroksiapatit, toksisitas, Rattus norvegicus 


\section{PENGANTAR}

Tulang adalah komponen utama pembentuk kerangka tubuh manusia (Nather dkk., 2005). Kerusakan tulang dapat terjadi karena trauma atau penyakit. Sampai saat ini pemakaian titanium merupakan cara yang paling sering dilakukan untuk perawatan kerusakan tulang (Anusavice, 2009). Selain pemakaian logam, alternatif lain untuk perawatan rekonstruksi tulang adalah pemakaian graf, yaitu pemakaian tulang baru atau sintetik untuk mengganti tulang yang rusak. Pemakaian graf yang berasal dari tubuh pasien sendiri (autograft) maupun dari donor (allograft) mempunyai kelemahan. Adanya kemungkinan iritasi sebagai reaksi penolakan graf menyebabkan perlu dikembangkannya graf sintetik (Pioletti dkk., 2006; Meijer dkk., 2007).

Hidroksiapatit sebagai komponen utama tulang adalah bahan bioaktif yang memiliki sifat osseointegrasi yang baik ketika digunakan dalam bidang ortopedi (Tin-Oo dkk., 2007). Osseointegrasi adalah kemampuan bahan untuk menyatu dengan tulang. Osseointegrasi merupakan syarat utama bahan yang digunakan untuk implan (Anusavice, 2009). Salah satu upaya untuk mendapatkan material graf yang aman adalah pengembangan material bioaktif hidroksiapatit menggunakan bahan dasar kalsit $\left(\mathrm{CaCO}_{3}\right.$, kalsium karbonat).

Hidroksiapatit merupakan biomaterial yang saat ini banyak dikembangkan sebagai material pengisi tulang pada bidang rekonstruksi, ortopedi, dan kedokteran gigi. Hidroksiapatit mempunyai biokompatibilitas yang baik, osteokonduktif, dan mempunyai sifat bonding yang baik terhadap tulang (Simon dkk, 2005). Hidroksiapatit telah banyak diteliti dan digunakan sebagai biomaterial (Suchaneck dan Yoshimura, 1998). Hidroksiapatit mempunyai sifat kimia, biologi, dan kristalografi mirip dengan tulang dan gigi (Herliansyah dkk, 2006). Hidroksiapatit yang berasal dari material lokal menunjukkan bahwa serbuk hidroksiapatit dapat disintesis dari kalsit menggunakan metode pemanasan microwave (Samsudin, 2010). Penelitian lebih lanjut terhadap hidroksiapatit kalsit menunjukkan bahwa uji in vitro terhadap perlekatan dan proliferasi sel fibroblas menunjukkan sifat biokompatibilitas yang baik (Sunarintyas dkk., 2010). Untuk dapat diterima sebagai material baru yang aman, material alternatif graf perlu dilakukan uji biokompatibilitas pada binatang sebelum digunakan pada manusia. Salah satu uji biokompatibilitas yang urgen untuk diketahui adalah uji toksisitas akut. Uji toksisitas akut dimaksudkan untuk mendapatkan informasi tentang gejala keracunan, penyebab kematian, urutan proses kematian dan rentang dosis yang mematikan hewan uji (Ngatijana,2006). Untuk memperoleh material sintetik pengganti tulang yang rusak dengan karakteristik: sifat mirip tulang alami, mudah diperoleh (menggunakan bahan lokal), dan murah (bahan dan teknologi lokal), maka dilakukan penelitian yang bertujuan mempelajari karakteristik toksisitas akut hidroksiapatit hasil sintesis dari kalsit Mojokerto, Jawa Timur sebagai alternatif material graf sintetis.

Rattus norvegicus adalah hidroksiapatit hasil sintesis dari kalsit OMYA (Mojokerto, Jawa Timur), hidroksiapatit impor (HA200 Waco, Jepang), kit pemeriksaan histopatologis, kit pemeriksaan darah rutin, EDTA, formalin 10\%, dan akuades. Alat yang digunakan diantaranya: timbangan analitis ketelitian 0,01 gr, peralatan bedah, sonde, spuit injeksi, dan mikroskop.

Prosedur penelitian dilakukan dengan urutan pelaksanaan sebagai berikut: perlakuan pemberian hidroksiapatit hasil sintesis dari kalsit pada hewan coba, pemeriksaan efek toksik sistemik, pemeriksaan kompatibilitas darah, dan pemeriksaan kompatibilitas organ. Perlakuan hewan coba dengan pemberian hidroksiapatit dilakukan di unit pemeliharaan hewan coba, LPPT UGM Yogyakarta. Pemeriksaan efek toksik sistemik dan kompatibilitas darah 
dilakukan di LPPT pusat UGM Yogyakarta. Pemeriksaan kompatibilitas organ dikerjakan di laboratorium Patologi Anatomi Fakultas Kedokteran Hewan UGM Yogyakarta.

Serbuk hidroksiapatit (HA) yang telah disintesis dari kalsit Mojokerto Jawa Timur dengan cara Samsudin (2010) ditimbang sebanyak 0,4 gram dimasukkan ke dalam cetakan kompaksi yang terbuat dari stainless steel. Cetakan yang berisi serbuk HA diletakkan pada alat kompaksi kemudian dilakukan penekanan sebesar $120 \mathrm{Mpa}$. Hasil cetakan adalah sampel penelitian berbentuk disk dengan diameter $10 \mathrm{~mm}$ dan tebal $3 \mathrm{~mm}$. Sampel HA disintering pada suhu $1450^{\circ} \mathrm{C}$ selama 2 jam. Sampel HA digerus di dalam cawan porselin hingga menjadi serbuk. Serbuk HA yang terbentuk digunakan untuk perlakuan pada hewan coba. Hidroksiapatit impor (HA 200-Waco, Jepang) juga dilakukan prosedur yang sama dilakukan kompaksi, sintering, dan digerus dalam cawan porselin hingga menjadi serbuk.

Perlakuan pemberian hidroksiapatit dan pemeriksaan efek toksik sistemik dilakukan menurut cara Ngatijan (2006). Tiga puluh ekor Rattus norvegicus digunakan dalam penelitian ini. Binatang yang menunjukkan berat badan normal setetah 1 minggu aklimatisasi dipilih menjadi subyek penelitian. Binatang dipelihara dalam suhu kamar $25 \pm 2^{\circ} \mathrm{C}$ dan kelembaban relatif $55 \pm$ $5 \%$. Makanan padat (Oriental NMF) dan air kran diberikan ad libitum. Tiap-tiap sepuluh Rattus norvegicus diberi 7,73 mg HA-Kalsit, HA-200 and akuades (kontrol) sebanyak 1 $\mathrm{ml}$ secara oral menggunakan sonde. Binatang diamati selama 7 hari setelah pemberian hidroksiapatit terhadap: kematian hewan, tingkah laku klinis (salivasi, pernafasan, dan suara). Pengamatan tingkah laku hewan coba selama7 hari di antaranya dilakukan sebagai berikut:
1. Suara: normal, meninggi, menurun, dan tidak normal lain.

2. Salivasi: salivasi, mulut kering, dan normal.

3. Pernafasan: apnea, dispnea, frekuensi meningkat, kedalaman bertambah, dan dangkal.

Pada akhir pengamatan hari ke 7 setelah pemberian hidroksiapatit per oral, dilakukan pemeriksaan kompatibilitas darah untuk darah rutin. Darah hewan coba yang telah diberi perlakuan diperiksa menggunakan spektrofotometer terhadap jumlah: WBC, RBC, HGB, HCT, MCV, MCH, MCHC, dan PLT.

Kompatibilitas organ diperiksa setelah pemberian hidroksiapatit pada hewan coba selama 7 hari. Hati dan ginjal diamati morfologinya secara makroskopis menggunakan mata telanjang. Organ kemudian dibuat persediaan histologis dan diperiksa menggunakan mikroskop perbesaran 400 kali.

\section{PEMBAHASAN}

Hasil pengamatan selama 7 hari setelah pemberian hidroksiapatit terhadap toksisitas sistemik hewan coba menunjukkan bahwa tidak ada hewan coba yang mati selama 7 hari. Ke-tigapuuh hewan coba semuanya hidup. Tidak ada tanda-tanda yang menunjukkan tingkah laku klinis hewan coba yang abnormal, baik pernafasan, suara, maupun salivasi.

Pemeriksaan darah rutin dari ketigapuluh hewan coba menunjukkan rerata seperti pada tabel 1 . Analisis varian 1 jalur dari pemeriksaan darah rutin menunjukkan tidak ada perbedaan yang bermakna diantara ketiga grup perlakuan pemberian hidroksiapatit (HA-kalsit, HA-200, dan akuades) ( $\mathrm{p}>0.05)$. 
Tabel 1. Rerata jumlah pemeriksaan darah rutin

\begin{tabular}{llll}
\hline Parameter & HA-Kalsit & HA-200 & Akuades \\
\hline 1. WBC & $9,4 \times 10^{3} \pm 1917,1$ & $9,3 \times 10^{3} \pm 1604,2$ & $9,3 \times 10^{3} \pm 1604,2$ \\
2. RBC & $7,5 \times 10^{6} \pm 53271$ & $8 \times 10^{6} \pm 56929$ & $7,8 \times 10^{6} \pm 50362$ \\
3. HGB & $14,5 \pm 0.3$ & $15,1 \pm 1,1$ & $14,7 \pm 0,6$ \\
4. HCT & $39,0 \pm 3,1$ & $42,9 \pm 3,5$ & $42,1 \pm 3,0$ \\
5. MCV & $53,9 \pm 0,6$ & $53,5 \pm 0,9$ & $54,2 \pm 0,9$ \\
6. MCH & $18,2 \pm 0,3$ & $18,8 \pm 0,4$ & $19 \pm 0,5$ \\
7. MCHC & $35,1 \pm 1,0$ & $35,1 \pm 0,7$ & $35 \pm 0,9$ \\
8. PLT & $1,1 \times 10^{6} \pm 32751$ & $1,0 \times 10^{6} \pm 6421$ & $1,1 \times 10^{6} \pm 15434$ \\
\hline
\end{tabular}

Pemeriksaan kompatibilitas organ menunjukkan tidak ada tanda-tanda abnormalitas yang ditemukan pada pemeriksaan morfologi hati dan ginjal pada pemeriksaan makroskopis. Semua organ mempunyai morfologi normal dan tidak berbeda di antara ketiga grup perlakuan. Pemeriksaan terhadap preparat histologi memperkuat hasil pemeriksaan secara makroskopis bahwa tidak ditemukan tanda-

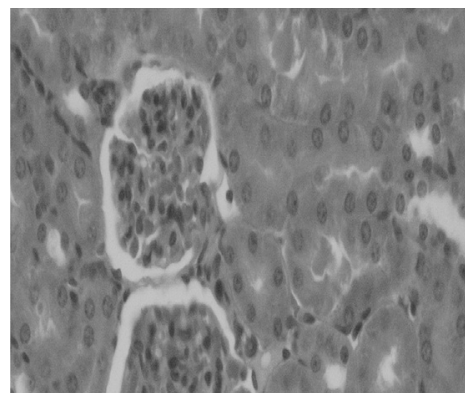

Gambar 3. Ginjal (akuades) tanda inflamasi maupun nekrose sel. Hasil pemeriksaan histopatologi seperti pada gambar 1 sampai dengan 6 .

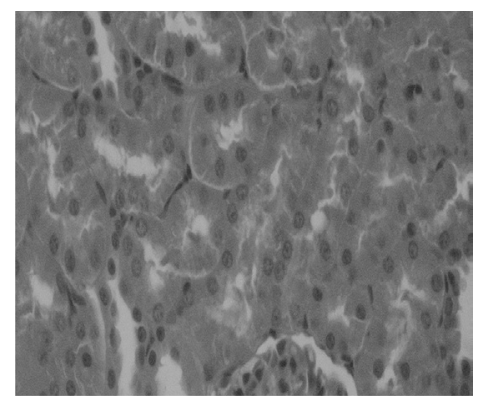

Gambar 1. Ginjal (HA-kalsit)

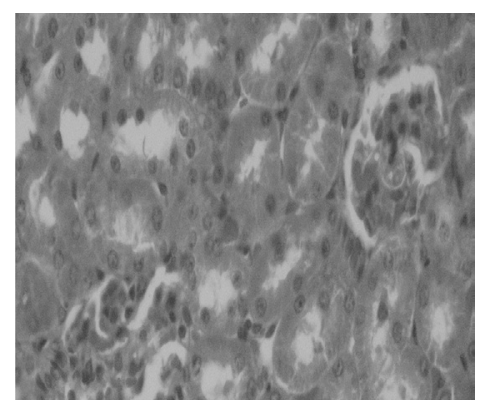

Gambar 2. Ginjal (HA-200)

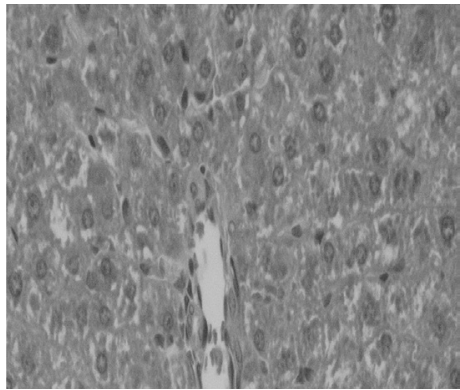

Gambar 4- Hati (HA-Kalsit)

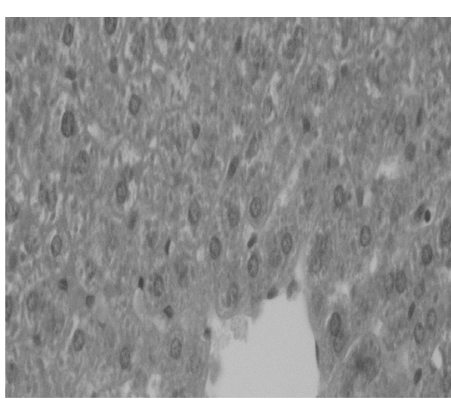

Gambar 5 - Hati (HA-200) 


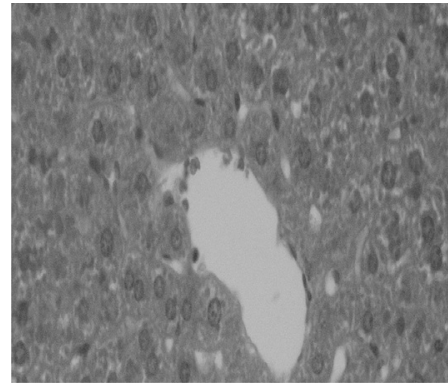

Gambar 6- Hati (akuades)

Pengamatan ini didesain untuk mendapatkan karakteristik toksisitas akut dari hdroksiapatit yang disintesis dari kalsit. Tidak ada tanda-tanda abnormalitas yang ditemukan pada kondisi umum yang tampak pada semua perlakuan. Tidak ditemukan kematian hewan coba selama 7 hari observasi. Tidak ada tanda-tanda yang menunjukkan ketidaknormalan pada tingkah laku klinis hewan coba (salivasi, pernafasan, suara) pada semua kelompok penelitian. Hasil penelitian yang diperoleh menunjukkan bahwa aplikasi sistemik HA yang disintesis dari kalsit Mojokerto, Jawa Timur tidak menunjukkan gejala toksisisitas akut pada hewan coba. Material dikatakan mempunyai karakteristik toksisitas sistemik akut jika setelah pemberian material tersebut selama 24 jam timbul efek keracunan atau kematian setelah 7 hari observasi (Zhengxian dkk, 1999).

Darah mengandung sel darah merah (erythrocytes), sel darah putih (leukocytes), dan platelets (thrombocytes) yang tersuspensi dalam cairan plasma. Tes pemeriksaan darah rutin pada umumnya meliputi pemeriksaan: WBC (white blood cell count), RBC (red blood cell count), hemoglobin, hematocrit, red cell indices (MCV, MCH, MCHC), dan penghitungan jumlah platelet (Ngatijan, 2006; The American Society for Clinical Laboratory Science, 2007). Pemeriksaan hematologi dilakukan untuk melengkapi pemeriksaan toksisitas material terhadap organ tubuh. Pada pemeriksaan kompatibilitas darah tampak bahwa tidak ada tanda-tanda abnormalitas jumlah darah rutin yang ditemukan. Semua jumlah darah rutin yang diperiksa berada pada jumlah yang normal. Analisis statistik menggunakan analisis varian satu jalur menunjukkan tidak ada perbedaan yang bermakna di antara ketiga grup perlakuan $(p>0,05)$. Hasil analisis ini menunjukkan bahwa pemberian HA yang disintesis dari kalsit Mojokerto, Jawa Timur tidak mempengaruhi sistem hematologi yang dapat menyebabkan toksisitas pada hewan coba.

Selanjutnya, tanda-tanda spesifik abnormalitas terhadap grup perlakuan hidroksiapatit tidak ditemukan baik pada pemberian HA-200 maupun HA-Kalsit pada pemeriksaan histopatologi. Tidak ditemukan adanya sel inflmasi maupun nekrosis pada gambaran preprat histologis. Hasil penelitian ini memperkuat hasil penelitian sebelumnya terhadap HA pada sel fibroblast yang menunjukkan tidak adanya potensi sitotoksisitas pada perlakuan HA (Pujianto dkk, 2006).

\section{SIMPULAN}

Hidroksiapatit yang disintesis dari kalsit yang berasal dari Mojokerto, Jawa Timur tidak mengindikasikan menimbulkan karakteristik toksisitas akut. Pemeriksaan hematologi menunjukkan kemiripan antara HA-Kalsit, HA-200 dan grup kontrol. Tidak ada tanda-tanda abnormalitas yang tampak pada pemeriksaan preparat histopatologi hati dan ginjal di antara ketiga grup. Berdasarkan hal ini HA yang disintesis dari kalsit Mojokerto Jawa Timur dapat direkomendasikan sebagai material alternatif pengganti tulang (graf sintetis). Untuk itu perlu dilakukan pemeriksaan lebih lanjut untuk dapat digunakan sebagai material graf sintetis yang aman, misalnya pemeriksaan osseointegrasi dari graf sintetis dan tulang yang direhabilitasi. 


\section{DAFTAR PUSTAKA}

AAnusavice KJ, 2009, Phllip's Science of Dental Materials $11^{\text {th }}$ ed. WB Saunders Co, Philadelphia, p.62-6.

Melis M., dan Mulder J, 2008, "Development and Biological Testing of Hydroxyapatite Gelatin Nanocomposite", Tesis, St Radbout Tandheelkunde Biomaterialen, Nijmegen.

Nather A., Ong HJC., Aziz Z, 2005, “Bone grafts and bone substitute". Imperial College Press, p. 3-11.

Petchey F. The bone, www.c14.com/bone. html - 15/30/2007.

Pioletti DP, Montjovent MO, Zambelli PY, Applegate L, 2006, "Bone tissue engineering using fetal cell therapy", Swiss Med Wkly, 136:557-60.

Tin-Oo MM.,Gopalakrishnan V., Samsudin AR., Al Salihi KA., Shamsuria O, 2007, "Antibacterial Property of locally produced hydroxyapatite". Archieves of orofacial Scie 2: 41-4.

Hench LL, Splinter RJ, Allen WC, Greenlee T, 1972, "Bounding mechanism at the interface of ceramics prosthetics materials". J. of Biomed Mater Res, 2: $117-41$.

Herliansyah MK, Hamdi M, Ektessabi MI, Wildan MW, 2006, "Fabrication of hydroxyapatite bone graft for implant application: a literature study", Kuala Lumpur, Proceedings of the First International Conference on Manufacturing and Material Processing, p, 559-64.

Martin RB, Chapman MW, Sharkey NA, Zissimos SL, Bay B, Shors EC, 1993, "Bone in growth and mechanical properties of coralline hydroxyapatite one year after implantation", Biomaterials, 14:341.
Meijer GJ, de Bruijn JD, Koole R, van Blitterswijk CA, 2007, "Cell-based bone tissue engineering". PLoS Med, 4:9.

McCabe JF, Walls AWG, 2008, “Applied Dental Materials", $9^{\text {th }}$ edition, Blackwell, Munksgaard, p, 89-100.

Ngatijana, 2006, Metodologi laboratorium dalam toksikologi, Yogyakarta, Bagian Farmakologi dan Toksikologi FK UGM, p, 137-69.

Ngatijan ${ }^{b}, 2006$, Toksikologi: Racun, keracunan dan terapi keracunan, Yogyakarta, Bagian Farmakologi dan Toksikologi FK UGM, p 5-22.

PujiantoE,SiswomihardjoW, Ana ID, Tontowi AE, Wildan MW, 2006, Cytotoxicity of hydroxyapatite synthesixed from local gypsum, Proceeding BME days 2006 Multidisiplinary synergy: towards a better community healthcare, ITB, Bandung, pp, 92-95.

Rho JY, Spearing LK, Zioupos P, 1998, Mechanical properties and the hierarchical structure of bone. Medical Engineering and Physics, Volume 20, p, 92-102.

Ruys AJ, Wei M, Sorrell CC, Dickson MR, Brandwood A, Milthorpe BK, 1995, Sintering effect on the strength of hydroxyapatite, Biomaterials, 16: 409.

Simon CG, Jr., Antonucci JM, Liu DW, Skrtic D, 2005, In vitro cytotoxicity of amorphous calcium phosphate composite. Journal of Bioactive and Compatible Polimers, 3: 279-95.

Samsudin, 2010, Analisis uji tekan dan porositas material kompaksi sinter $\mathrm{HA}-\mathrm{ZrO}$ sebagai material substitusi tulang, Thesis S2, Minat Rekayasa Biomedis, Yogyakarta, Sekolah Pascasarjana UGM.

SuchaneckW, Yoshimura M, 1998, "Processing and properties of hydroxyapatite 
JURNAL 『ERKNOSAINS | VOL 2, NO. 1, DESEMBER 2012 ; 48-54

based biomaterials for use as hard tissue replacement implants", Journal Material Research, 13(1): 94-117.

Sunarintyas S, Yustisia Y, Tontowi AE,
2010, Pengaruh aplikasi sericin pada permukaan hidroksi apatit terhadap perlekatan dan proliferasi sel, Laporan Penelitian Hibah Pasca, Yogyakarta, Sekolah Pascasarjana Universitas Gadjah Mada.
The American Society for Clinical Laboratory Science. Hematology Test. Laboratory Science, Maryland, 2007, pp 1-2.

Zhengxian Z, Ke B, Higa T, 1999, "Study on chronic toxicity test of EM-X in rats", The $5^{\text {th }}$ Congress of World Institute for Ecology and Cancer, Asian Chapter, Okinawa, Japan, pp 55. 